stories of damaged lives, difficult childhoods, shattered dreams. But, here in Bilbao, I was heartened to learn about a really radical service which supports and protects drug users, offering the chance to improve futures and heal the wounds of the past.

\section{Meg Thomas}

\section{Acknowledgements}

Many thanks to the Médicos del Mundo team at the Sala de Consumo Supervisado, Bilbao for their hospitality and for allowing me some insight into the service.

\section{REFERENCES}

1. Nieto M. San Francisco: marginalidad en el centro: Los guetos en Espana. San Francisco: marginalisation in the town centre: ghettos in Spain. Madrid: Elpais.com, 2006

2. Gutiérrez Estíbaliz B. Una Sala de Consumo Supervisado en Bilbao: Evolución y resultados tras dos años de funcionamiento. A drug consumption room in Bilbao: Progress and results after 3 years in operation. Report for the Cadiz government. Cadiz: 2002

3. Hedrich D, European Monitoring Centre for Drugs and Drug Addiction. European report on drug consumption rooms. Luxembourg: Office for Official Publications of the
European Communities, 2004

4. Joseph Rowntree Foundation. The Report of the Independent Working Group on Drug Consumption Rooms. York: Joseph Rowntree Foundation, 2006

5. Sheldon T. More than a quick fix. BMJ 2008; 336: 68-69.

6. Laurance J. Heroin: The solution? 2006, The Independent. http://www.independent.co.uk/news/uk/crime/heroin-thesolution-480734.html (accessed 9 Oct 2008).

7. Anonymous. Editorial: an injection of reality. 2006, The Independent. http://www.independent.co.uk/opinion/ leading-articles/leading-article-an-injection-of-reality480718.html (accessed 9 Oct 2008).

DOI: 10.3399/bjgp08X342714

\title{
Down the rabbit hole
}

'Down, down, down. Would the fall never come to an end?' Just as Alice followed the white rabbit, so have all of us gone down the economic hole and we don't know where it will end. The freefall that started in the US and has affected everyone else comes from the economic interdependency of the world economy. That is not a bad thing. We all share the planet. But, not only has the unregulated greed of Wall Street indebted my grandchildren, but it has also threatened any serious talk about healthcare reform, yet again. Health reform has dropped from the major domestic concern of the public a year ago to ranking down there with agricultural policy as we head into the final weeks of the election. Losing one's retirement or house or paying for gas to drive to a job that may not be there trumps paying the doctor. The healthcare crisis, of course, will be back and be more imposing after the realities of the financial meltdown becomes clear.

Opportunities for moving health reform may come out of this costly underwriting of banks and investment firms. Even though the large majority of Americans favour an overhaul of the system, policy theorists say it hasn't happened because the middle class has not yet felt enough pain to risk change. Now, as unemployed bankers, white collar workers, executives, financial advisors all look at a life without health insurance and maybe even join laid off auto workers and undocumented immigrants at the free clinics, there is a higher likelihood of serious talk about a basic level of care for everyone.

Universal health care is an economic issue that Americans disguise as a 'values' issue. 'Choice' is second only to 'change' as the most used word in America. Choice is a value when the country is so flush that health plans, like brands of breakfast cereals, each offer something different. But, cereal is cereal to those who have no food. So when the ranks of those who have no choice because they have no insurance grow, including millions from the celebrated middle class, there may be greater hope for agreeing on the value of everyone being in this together. The tipping point toward a system of universal coverage in the US may just be coming into view.

Barack Obama's story is one of the most compelling and moving ones in America. But the homestretch of this exhausting political circus known as the US Presidential election continues to have him portrayed by his rivals as an 'elitist', rather than the mixed race son of a hardscrabble Midwestern family, raised by a single mother on the edge of poverty who became the educated, community grounded person that he is today. 'Elitist' means he speaks clearly and in full sentences, he talks about social justice, equality and has an interesting, accomplished wife and children. His opponent has a stirring story and, because he is 72 years old, a more complicated one.

John McCain endured things few of us can imagine as a POW and seemed determined to use his experience to be a different and less predictable public official. But in the past 6 months, he has become nothing but predictable, despite his protestations to the contrary. His willingness to choose to run with someone whose entire international experience comprises living in a state between Russia and Canada and visiting neither is portrayed as bold by his loyalists and as thumbing his nose at the rest of the world by everyone else.

Obama's plan for universal coverage depends heavily on employer-funded insurance, uses tax relief for small businesses and covers the uninsured through pools and expanding Medicaid. He wants to create savings through managing drug costs and squeezing insurance companies, the two most powerful health lobbies. McCain insists that market competition will sort everything out and that giving families tax breaks with which to buy insurance will drive prices down. He is less clear about the increasing numbers of uninsured, however. His plan doesn't mention them. And he proposes to deal with the issue of access to care by putting clinics in shopping malls.

The deadline for this piece comes shortly before the election. I don't know the outcome. A vote for progressive, thoughtful, politics that DOES bring the Change We Need may still be possible in this country. But we have been stupid before and may be again. Look who we have in the White House. When Alice was leaving the Mad Hatter's Tea Party and opened the gate into the Garden of the Red Queen, she said 'Now, I'll manage better this time.' Whatever lurks on the other side of the next election in the US may be better. We can certainly hope so. Another possibility is that we might all lose our heads.

\section{John Frey}

DOI: 10.3399/bjgp08X342723 